\title{
Complex processing of titanium-rare metal raw material
}

\author{
Mikhail Medkov ${ }^{1}$, Galina Krysenko ${ }^{1 *}$, Dantiy Epov ${ }^{1}$, Pavel Sitnik ${ }^{2}$ and Valentin \\ Avramenko ${ }^{1,2}$ \\ ${ }^{1}$ Institute of Chemistry of Far East Branch of the Russian Academy of Sciences, Vladivostok, Russia \\ ${ }^{2}$ Far Eastern Federal University, Vladivostok, Russia
}

\begin{abstract}
The paper is devoted to investigation of the complex processing of titanium-rare metal raw materials with ammonium hydrodifluoride. It is stated that fluorination of the main components of the mineral raw materials with ammonium hydrodifluoride proceeds with formation of complex ammonium fluorometallates and simple fluorides. It is showed that in the process of aqueous leaching of the fluorinated mineral raw material niobium and tantalum completely pass into solution together with titanium, iron, and silicon fluoroammonium salts while all the rare-earth elements stay in the insoluble residue as complex fluorosodium salts together with $\mathrm{CaF}_{2}$. The method of separation of the fluoroammonium salts with obtaining marketable products and isolation of the rare-earth elements from the insoluble residue is offered.
\end{abstract}

\section{Introduction}

In most cases, the home-produced rare-metal raw materials contain also titanium though its content is less than that in the widespread kinds - ilmenite and rutile. The typical peculiarity of the unconventional titanium and rare-metal raw materials in Russia from the both exploiting deposits (Lovozerskoye - loparite ores) and perspective for development (Afrikandskoye - perovskite ores) consists in their complex multicomponent composition and low concentrations of the rare metals.

The most studied and widespread way of processing of the titanium and rare-metal raw materials is the sulphuric acid method that is conditioned by simplicity of its equipment and use of cheap and available reagents [1]. At the same time, the sulphuric acid schemes are characterized by large material streams as well as an increased amount of liquid and solid waste. For loparite concentrate, the chlorine technological scheme (named according to the main operation) was realized in the industrial scale [2].

Lately, the fluorination methods of raw materials processing attract great attention. It is especially profitable to use such a way for processing of the polymetallic raw materials because it lets to widen variety and profundity of the valuable components isolation [3]. In this connection, breakdown of a mineral raw material with $\mathrm{NH}_{4} \mathrm{HF}_{2}$ is particularly interest because of technological attractivity of the way of isolation of the components from the

'Corresponding author: krisenko@ich.dvo.ru 
natural material via formation of ammonium fluorometallates [4]. Use of ammonium hydrodifluoride lets to achieve breakdown of a raw material at lower temperatures; the fluorination by-products (water and ammonia steam) do not contain fluorine that provides ecological safety of the production and lets to recycle them in condensed state in the processes of ammonia hydrolysis. Moreover, in the hydrodifluoride processing, regeneration of the fluorinating agent is comparatively easily realized. Comparison of the technical and economic indicators of the existing methods of pigment titanium dioxide production showed that use of the fluoride technology let to lower the pigment production cost by half [5].

The present work contains the results of investigation of perspective of the titanium-rare metal raw material complex processing by breakdown of the concentrate with ammonium hydrodifluoride.

\section{Materials and methods}

Perovskite concentrate of Afrikand deposit and loparite concentrate of Lovozersk deposit were used as the samples. Ammonium hydrodifluoride (analytical grade) served as the fluorinating agent.

Breakdown of the raw material was carried out in a nickel container which was put into a reactor with electric heating. The weighed amounts 50-100 g were used. Fluorination process proceeded at the temperature $160-180{ }^{\circ} \mathrm{C}$ and the mass ratios of the concentrate to the fluorinating agent equaled $1: 1.7$ and 1:1.9.

Leaching of the soluble fluoroammonium salts from the fluorinated concentrate was carried out by triple treatment of the product with water at the ratio solid:liquid $=1: 5$ and following filtration through a "blue band" filter. The process of pyrohydrolysis proceeds at the temperatures 700 and $800{ }^{\circ} \mathrm{C}$ with the constant water steam supply at a speed of 0.7 $\mathrm{L} / \mathrm{min}$.

The thermogravimetric investigation was carried at a Q-1000 device in platinum crucibles in air at a heating rate of $2.5 \mathrm{deg} \mathrm{min}^{-1}$ using the weighed amounts of 100-200 $\mathrm{mg}$.

The changes of the substance in the processes of heating and leaching were controlled according to the loss of the initial mass as well as by the X-ray diffraction find IR spectroscopy methods.

The X-ray diffraction patterns of the samples were recorded at a D8 ADVANCE automatic diffractometer with rotation of a sample in $\mathrm{CuK} \alpha$ radiation. The $\mathrm{X}$-ray diffraction analysis was carried out using the EVA search programme and PDF-2 powder database. The IR spectra were registered at a SHIMADZU spectrometer. The samples were prepared as a suspension in Vaseline oil.

The contents of the main components at the various stages were determined by the Xray fluorescence method at a Shimadzu EDX 800 HS spectrometer (tube with the rhodium anode, vacuum) at the room temperature using the tablets with polytetrafluoroethylene.

The content of thorium and its decay products in the samples was controlled by the radiometric method. The natural long-lived $\alpha$-radiating ${ }^{232} \mathrm{Th}$ isotope, which initial activity in the sample was determined by $\gamma$-radiation of the ${ }^{212} \mathrm{~Pb}$ isotope, was used as the tracer.

\section{Results and discussion}

According to the X-ray diffraction data perovskite concentrate was presented mainly by perovskite $\mathrm{CaTiO}_{3}$ and hematite $\mathrm{Fe}_{2} \mathrm{O}_{3}$. It also contained silicon, niobium, aluminium, rareearth and other elements. Loparite concentrate, on the whole, consisted of loparite $(\mathrm{Na}, \mathrm{Ce}$, 
$\mathrm{Ca})(\mathrm{Ti}, \mathrm{Nb}) \mathrm{O}_{3}$ with attendant silicon, iron, aluminium, thorium, and widely distributed rock-forming mineral aegirine which is sodium-iron silicate.

The thermogravimetric study showed that interaction of perovskite concentrate with $\mathrm{NH}_{4} \mathrm{HF}_{2}$ (Fig. 1, a) started in the dry mixture at $100{ }^{\circ} \mathrm{C}$ with heat liberation; above $120{ }^{\circ} \mathrm{C}$ one could observe the endothermic effect of the fluorination agent fusion, and further, the reaction proceeded in the melt with the maximum rate at $155^{\circ} \mathrm{C}$ and was completed at 200 ${ }^{\circ} \mathrm{C}$ [6]. Interaction of loparite concentrate with $\mathrm{NH}_{4} \mathrm{HF}_{2}$ also starts in the dry mixture at 100 ${ }^{\circ} \mathrm{C}$ with heat liberation, above $121{ }^{\circ} \mathrm{C}$ the endothermic effect of the fluorinating agent melting is added to this process, and further, the reaction proceeds in the melt with the maximum rate at $165^{\circ} \mathrm{C}$ and is completed at $205^{\circ} \mathrm{C}$ (Fig. 1, b) [7].
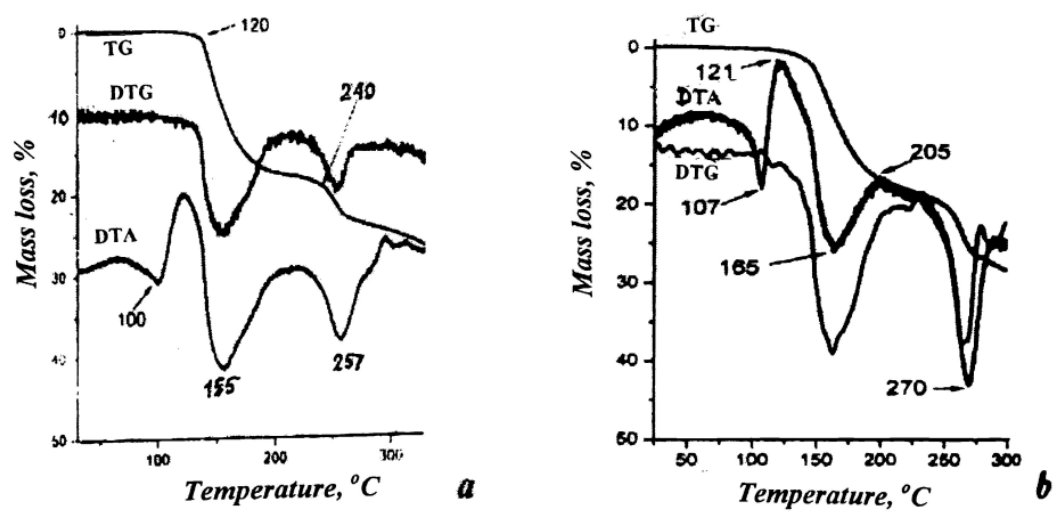

Fig. 1. Thermogravimetric curves of interaction with $\mathrm{NH}_{4} \mathrm{HF}_{2}: a$ - perovskite concentrate; $b$ - loparite concentrate.

The product isolated at $200{ }^{\circ} \mathrm{C}$ is the mixture of fluoroammonium salts $\left(\mathrm{NH}_{4}\right)_{2} \mathrm{TiF}_{6}$, $\left(\mathrm{NH}_{4}\right)_{3} \mathrm{FeF}_{6}$, and $\left(\mathrm{NH}_{4}\right)_{2} \mathrm{SiF}_{6}$ and $\mathrm{CaF}_{2}$ in the case of perovskite concentrate while for loparite concentrate such mixture consists of $\left(\mathrm{NH}_{4}\right)_{2} \mathrm{TiF}_{6},\left(\mathrm{NH}_{4}\right)_{3} \mathrm{NbOF}_{6}$, and $\left(\mathrm{NH}_{4}\right)_{2} \mathrm{SiF}_{6}$. Thus, fluorination of concentrates can be presented by the following equation:

$\mathrm{CaTiO}_{3}+4,5 \mathrm{NH}_{4} \mathrm{HF}_{2}=\mathrm{CaF}_{2}+\left(\mathrm{NH}_{4}\right)_{3} \mathrm{TiF}_{7}+1,5 \mathrm{NH}_{3}+3 \mathrm{H}_{2} \mathrm{O}$

$(\mathrm{Na}, \mathrm{Ce}, \mathrm{Ca})(\mathrm{Ti}, \mathrm{Nb}) \mathrm{O}_{3}+\mathrm{NH}_{4} \mathrm{HF}_{2} \rightarrow\left(\mathrm{NH}_{4}\right)_{2} \mathrm{TiF}_{6}+\left(\mathrm{NH}_{4}\right)_{3} \mathrm{NbOF}_{6}+\mathrm{NH}_{4} \mathrm{CeF}_{4}+\mathrm{NaF}+$ $\mathrm{CaF}_{2}+\mathrm{NH}_{3} \uparrow+\mathrm{H}_{2} \mathrm{O}$.

Kinetic investigations of the fluorination processes were carried out basing on amounts of liberated ammonia. The results are presented in Fig. 2.
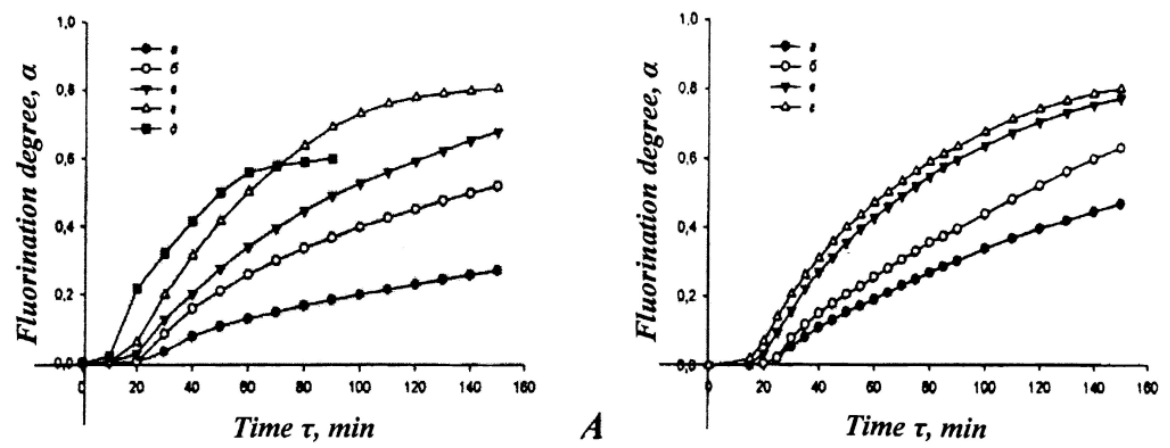

Fig. 2. Dependence of fluorination degree on time at various temperatures: $A$-perovskite concentrate $\left(a-130, b-140, c-150, d-160, e-150^{\circ} \mathrm{C}\right.$ и $\left.53 \% \mathrm{NH}_{4} \mathrm{HF}_{2}\right) ; B$ - loparite concentrate $\left(a-140, b-150, c-160, d-165^{\circ} \mathrm{C}\right)$. 
The kinetic dependence clearly shows that in case of use of the stoichiometric amount of the fluorinating agent the complete breakdown of the concentrates is not achieved that is connected with $\mathrm{NH}_{4} \mathrm{HF}_{2}$ melting and its following partial evaporation. With a deficiency of the fluorination agent (Fig. $2 A$, curve $e$ ) interaction proceeds without visible formation of the melt and $\mathrm{NH}_{4} \mathrm{HF}_{2}$ evaporation that lets to breakdown the mineral raw material without use of an excess of the fluorinating agent provided that the fluorination process is carried out in several stages.

Basing on the experimental data we calculated the values of activation energy, order of the reactions, and constants of action for interaction of the concentrates with $\mathrm{NH}_{4} \mathrm{HF}_{2}$. For calculation we used the general topochemical Kolmogorov-Erofeev equation [8]. Analysis of variations of the constants of action showed that at the melting temperature of the fluorinating agent interaction of the both concentrates with ammonium hydrodifluoride proceeded at the border of the diffusion and kinetic areas. In the melt of the fluorination agent interaction proceeded in the kinetic area and at a higher rate. The low values of activation energy for interaction with ammonium hydrodifluoride $(58.8$ and $74.4 \mathrm{~kJ} / \mathrm{mole}$ for perovskite and loparite concentrate, respectively) show that such concentrates must be easily broken down with this agent.

Basing on the results of the thermogravimetric and kinetic analysis we carried out breakdown of perovskite and loparite concentrates at $160-170$ and $170-180{ }^{\circ} \mathrm{C}$ and at the mass ratios of the concentrate to the fluorinating agent $1: 1.9$ and $1: 1.7$, respectively. The fluorination process was realized by steps, with addition of the necessary amounts of $\mathrm{NH}_{4} \mathrm{HF}_{2}$ in the two stages. The fluorinated concentrates were friable grey powders. According to the X-ray diffraction data they consisted of the mixture of the complex fluoroammonium salts and $\mathrm{CaF}_{2}$.

Fluoroammonium salts of titanium, iron, niobium, and silicon are readily soluble in water, therefore it was reasonable to transfer these salts into solution by aqueous leaching at the following stage of the processing. Our study showed that the insoluble residue presented 24-26\% of the initial fluorinated product mass. According to the X-ray diffraction data this residue was $\mathrm{CaF}_{2}$ in the case of perovskite concentrate and $\mathrm{NaCeF}_{4}-$ for loparite one while the evaporated filtrate consisted of the mixture of fluoroammonium salts titanium, niobium, iron, and silicon. The X-ray fluorescence data on the elemental composition confirm that aqueous leaching of the fluorinated concentrate results in the complete transfer of fluoroammonium salts into the filtrate while the rare-earth elements stay in the insoluble residue.

Niobium, and tantalum can be selectively separated from titanium, silicon, and iron by the following processing of the filtrate using, e.g. extraction. Extraction separation of niobium and tantalum from titanium is carried out with aliphatic spirits when these metals transfer into the organic phase [9]. It is reasonable to separate titanium, iron, and silicon fluoroammonium salts by the sublimation method because the high sublimation temperatures of iron fluorides create conditions for profound separation of volatile ammonium fluorometallates (titanium and silicon) and non-volatile iron salts. The residue after sublimation of fluoroammonium salts titanium and silicon is the slime in which iron exists as $\mathrm{FeF}_{2}$. Reduction of this slime in hydrogen atmosphere which intensively proceeds at $520-620{ }^{\circ} \mathrm{C}$ results in obtaining iron powder while its pyrohydrolysis - in obtaining other valuable by-product - red pigment (ochre). The mixture of ammonium hexafluorotitanate and hexafluorosilicate is easily separated at $\geq 400{ }^{\circ} \mathrm{C}$ under influence of steam in the process of the sublimate pyrohydrolysis on the stage of $\mathrm{TiO}_{2}$ obtaining [10].

According to the X-ray diffraction data the insoluble residue prepared by leaching the fluorinated loparite concentrate is $\mathrm{NaCeF}_{4}$. The $\mathrm{X}$-ray diffraction pattern of the sample obtained after burning in air at $650^{\circ} \mathrm{C}$ displays the reflexes of $\mathrm{CeO}_{2}, \mathrm{LaOF}$, and $\beta-\mathrm{NaNdF}_{4}$ that indicates to the presence of lanthanum and neodymium fluorosodium complex salts in 
the insoluble residue which are isostructural with $\mathrm{NaCeF}_{4}$ [11]. The elemental composition of the insoluble residue (re-counted for fluorides) is presented in Table 1.

Table 1. X-ray fluorescence results of elemental composition of residue prepared by loparite concentrate processing

\begin{tabular}{|l|c|c|c|c|}
\hline Compound & $\mathrm{LnF}_{3}$ & $\mathrm{NaF}$ & $\mathrm{CaF}_{2}$ & $\mathrm{ThF}_{4}$ \\
\hline Concentration (wt.\%) & 74,4 & 15,5 & 9,0 & 1,0 \\
\hline
\end{tabular}

Thus, the insoluble residue obtained by aqueous leaching of the fluorinated concentrate is the mixture of cerium, lanthanum and neodymium fluorosodium complex salts $\mathrm{NaLnF}_{4}$ and calcium fluoride. It also contains thorium. The main phase in loparite concentrate processing is $\mathrm{NaLnF}_{4}$ while in the case of perovskite concentrate $-\mathrm{CaF}_{2}$.

In order to isolate the rare-earth elements from the insoluble residue we studied possibility to dissolve this product in nitric acid.

Calcium fluoride is a slightly soluble compound. Solubility of $\mathrm{CaF}_{2}$ as a function in nitric acid solutions of various concentrations at various temperatures was described in [12]. It was stated that it was maximum in $6 \mathrm{M} \mathrm{HNO}_{3}$. The cause of decrease of $\mathrm{CaF}_{2}$ solubility with increase of the acid concentration above $6 \mathrm{M}$ was not investigated but it was suggested it was connected with the salting-out effect.

The investigation carried out on the model mixtures of the rare-earth fluorosodium salts and $\mathrm{CaF}_{2}$ showed that in the case of acid leaching one could observe interaction of these components with $\mathrm{HNO}_{3}$ resulting in obtaining respective nitrates as well as their dissolving. $\mathrm{HNO}_{3}$ amount necessary for dissolving of the samples was determined from the equation

$$
\mathrm{NaLnF}_{4}+4 \mathrm{HNO}_{3}=\mathrm{Ln}\left(\mathrm{NO}_{3}\right)_{3}+\mathrm{NaNO}_{3}+4 \mathrm{HF}
$$

and from the solubility isotherm $\mathrm{CaF}_{2}-\mathrm{HNO}_{3}$ [12].

The study showed that degree of dissolving of the above-mentioned model mixtures increased with use of more diluted acid solutions, with the temperature rise, and with longer operation time. The elemental analysis indicated that after this treatment, the percentage contents of the rare-earth elements and calcium in the evaporated filtrate was approximately the same as in the initial sample. Thus, acid leaching of the insoluble residue failed in separation of the rare-earth fluorosodium salts from calcium. It is reasonable to transform these complexes into compounds which could more easily interact with $\mathrm{HNO}_{3}$, e.g. by pyrohydrolysis, into oxides or oxyfluorides.

Pyrohydrolysis of the insoluble residue of loparite concentrate at $800{ }^{\circ} \mathrm{C}$ results in obtaining the product consisted, according to the $\mathrm{X}$-ray diffraction data, of the mixture of $\mathrm{CaF}_{2}, \mathrm{NaF}, \mathrm{CeO}_{2}, \mathrm{NdF}_{2}, \mathrm{NaLnF}_{4}$, and $\mathrm{Na}_{3} \mathrm{Th}_{2} \mathrm{~F}_{11}$. Changing the hydrolysis conditions (temperature, rate of steam supply, duration of the process) we could not prepare a product free of $\mathrm{NaLnF}_{4}$ that could be connected with incongruent melting of $\mathrm{NaLnF}_{4}$ within this temperature range with obtaining the rare-earth trifluorides [13].

The rare-earth fluorosodium salts were decomposed by concentrated hydrofluoric acid at slight heating. The residue after dilution of the resulting mixture with water consisted of the rare-earths and calcium fluorides and the evaporated filtrate - NaF. The radiometric data on thorium content shows that after such treatment thorium completely stayed in the insoluble residue. Pyrohydrolysis of this residue at $800{ }^{\circ} \mathrm{C}$ resulted in obtaining the product which is the mixture of $\mathrm{CeO}_{2}, \mathrm{LnOF}, \mathrm{NdOF}$, and $\mathrm{CaF}_{2}$.

Investigation of dissolution of the pyrohydrolysis product in nitric acid showed that acid leaching proceeded with interaction of cerium oxide and lanthanum and neodymium oxyfluorides with formation of nitrates. Moreover, one could observe a partial calcium transfer into solution as $\mathrm{Ca}\left(\mathrm{NO}_{3}\right)_{2}$, according to the solubility isotherm $\mathrm{CaF}_{2}-\mathrm{HNO}_{3}$. The $\mathrm{X}$-ray diffraction data proved that the insoluble residue consisted of $\mathrm{CaF}_{2}$. The acid 
volumes necessary for dissolution of the pyrohydrolysis product were calculated by the equations:

$$
\begin{aligned}
& \mathrm{CeO}_{2}+4 \mathrm{HNO}_{3}=\mathrm{Ce}\left(\mathrm{NO}_{3}\right)_{4}+2 \mathrm{H}_{2} \mathrm{O} \\
& \mathrm{LnOF}+3 \mathrm{HNO}_{3}=\mathrm{Ln}\left(\mathrm{NO}_{3}\right)_{3}+\mathrm{HF}+\mathrm{H}_{2} \mathrm{O} \text { and } \\
& \mathrm{NdOF}+3 \mathrm{HNO}_{3}=\mathrm{Nd}\left(\mathrm{NO}_{3}\right)_{3}+\mathrm{HF}+\mathrm{H}_{2} \mathrm{O} .
\end{aligned}
$$

Acid leaching was carried out with the stoichiometric amount of $\mathrm{HNO}_{3}$ and with its excess. It was shown that the degree of dissolution of the pyrohydrolysis product achieved $\sim 90 \%$. The results of the elemental analysis for the rare-earths and calcium in the evaporated to the dry salts filtrates are presented in Table 2.

Table 2. Degree of the rare-earths and calcium transfer into solution in acid leaching of the pyrohydrolysis product (weight of the initial sample $1 \mathrm{~g}$ )

\begin{tabular}{|c|c|c|c|c|}
\hline \multicolumn{2}{|c|}{ Conditions of experiment } & $\begin{array}{c}12 \mathrm{M} \mathrm{HNO}_{3} ; \\
\text { stoichiometry } \\
(\mathrm{V}=2.5 \mathrm{ml})\end{array}$ & $\begin{array}{c}12 \mathrm{M} \mathrm{HNO}_{3} ; \\
100 \% \text { excess } \\
(\mathrm{V}=5 \mathrm{ml})\end{array}$ & $\begin{array}{c}3 \mathrm{M} \mathrm{HNO}_{3} ; \\
\text { stoichiometry } \\
(\mathrm{V}=10 \mathrm{ml})\end{array}$ \\
\hline \multicolumn{2}{|c|}{ Insoluble residue mass, $g$} & 0,1097 & 0,0973 & 0,0856 \\
\hline \multirow{2}{*}{$\begin{array}{c}\text { Content in } \\
\text { evaporated } \\
\text { filtrate, mass } \%\end{array}$} & $\mathrm{REE}$ & 43,1 & 41,9 & 40,4 \\
\cline { 2 - 5 } & $\mathrm{Ca}$ & 0,7 & 1,1 & 1,4 \\
\hline $\begin{array}{c}\text { Degree of } \\
\text { extraction, } \%\end{array}$ & $\mathrm{REE}$ & 98,0 & 96,6 & 96,0 \\
\cline { 2 - 6 } & $\mathrm{Ca}$ & 5,4 & 9,3 & 13,0 \\
\hline
\end{tabular}

One can see from the Table that in the case of leaching of the pyrohydrolysis product with nitric acid the degree of dissolution of the sample under investigation is influenced by the liquid phase volume: the degree of dissolution increases with increase of the volume of the liquid phase. However, the degree of the rare-earth transfer into the solution decreases that can be connected with increase of the degree of $\mathrm{CaF}_{2}$ dissolution in $\mathrm{HNO}_{3}$ under this conditions and respective rise of fluoride-ions content in the solution.

Deactivation of the resulted nitric solution was carried out by co-precipitation of thorium with barium sulfate. Under these conditions, at the same time with deactivation, additional removal of calcium and strontium impurities takes place because of their turning into slightly soluble sulfates. As a result, the solution contains only rare-earth and ammonium nitrates. This nitrate solution may be an initial product for obtaining rareearths compounds, e.g. carbonates, oxides, etc. Thus, for processing with the purpose of the rare-earths extraction from solutions the stepped neutralization methods are widely used. $\mathrm{pH}$ value at the beginning of rare-earth hydroxides precipitation in the process of lanthanide hydroxides precipitation from nitrate solutions varies from 6.95 (Y) to 7.82 (La).

Our investigation showed that addition of ammonia to the nitrate solution to $\mathrm{pH} \approx 7$ resulted in formation of a gelatinous precipitate which coagulates at slight heating. According to the X-ray diffraction data this precipitate was the mixture of rare-earth oxides. Its composition determined by the X-ray fluorescent method was following (mass \%): $\mathrm{Ce}_{2} \mathrm{O}_{3}$ (59.2), $\mathrm{Nd}_{2} \mathrm{O}_{3}$ (19.4), $\mathrm{La}_{2} \mathrm{O}_{3}$ (17.8), $\mathrm{Y}_{2} \mathrm{O}_{3}(0.08)$.

\section{Conclusions}

Interaction of loparite and perovskite concentrate $\mathrm{s}$ with ammonium hydrodifluoride was studied. The ways of carrying out of their complex processing with isolation of all valuable 
compounent in such breakdown were determined. The offered scheme of complex processing is universal and may be used not only for loparite and perovskite concentrates but also for other concentrates containing rare-earth elements.

\section{References}

1. Rare and scattered elements. Chemistry and technology. In 3 volumes. / Under the editorship of Korovin S.S. Moscow: MISIS. II. P. 461. (1996).

2. James B. Hedrick, Shyama P. Sinha, Valery D. Kosynkin. J. of Alloy and Compounds. 250 (1-2). P. 467-470. (1997).

3. Karelin V.A., Karelin A.I. Fluoride processing of rare-metals concentrates. Tomsk: NTL (Scientific and technical literature). 221 p. (2004).

4. Rakov E.G. Science and technical resume. Inorganic chemistry. Moscow: VINITI (National institute of scientific and technical information). 15. 154 p. (1988).

5. Andreev A.A. Fluoride processing of pigment titanium dioxide production. // Theses of reports of all-Russ. theoretical and practical conference. Tomsk 25-26 June 2009. Tomsk: Publisher Tomsk Polytechnic University. P. 27. (2009).

6. Krysenko G.F., Epov D.G., Medkov M.A, et al. Journal "Theoretical Foundations of Chemical Engineering". 50 (4), P. 589-593. (2016).

7. Krysenko G.F., Epov D.G., Medkov M.A, et al. Interaction of loparite concentrate with ammonium hydrodifluoride. // Russian Journal of Applied Chemistry. 89 (4). P. 540546. (2016).

8. Boldyrev V.V. Methods of investigation of the kinetics of thermal decomposition of solids. Tomsk: Tomsk. Gos. Univ. P. 62. (1958).

9. Rare and scattered elements. Chemistry and technology. In 3 volumes. / Under the editorship of Korovin S.S. Moscow: MISIS. I. P. 324-326. (1996).

10. Melnichenko E.I. The fluoride processing of rare-metal ores of Far East. Vladivostok: Dalnauka. 268 p. (2002).

11. J.H. Burns. Crystal Structure of Hexagonal Sodium Neodymium Fluoride and Related Compounds. // J. Inorganic Chemistry. 4 (6). P. 881-886. (1965).

12. Malcolm W. Wilding and Donald W. Rhodes. Solubility Isotherms for Calcium Fluoride in Nitric Acid Solution. // Journal of Chemical and Engineering Data. 15 (2). P. 297-298. (1970).

13. Sobolev B.P. The Rare earth trifluorides. Barcelona: Institut d'Estudis Catalans. 520 p. (2000). 